\title{
Quantifying sea surface temperature ranges of the Arabian Sea for the past 20000 years
}

\author{
G. M. Ganssen ${ }^{1}$, F. J. C. Peeters ${ }^{1}$, B. Metcalfe ${ }^{1}$, P. Anand ${ }^{2}$, S. J. A. Jung ${ }^{3}$, D. Kroon ${ }^{3}$, and G.-J. A. Brummer ${ }^{4}$ \\ ${ }^{1}$ Section Marine Biogeology, Institute of Earth Sciences, Faculty of Earth- and Life Sciences, VU University Amsterdam, \\ de Boelelaan 1085, 1081 HV Amsterdam, The Netherlands \\ ${ }^{2}$ Faculty of Science, Open University, Walton Hall, Milton Keynes, MK7 6AA, UK \\ ${ }^{3}$ School of Geosciences, University of Edinburgh, Edinburgh, UK \\ ${ }^{4}$ Royal NIOZ, Landsdiep 4, 1797 SZ't Horntje, Texel, The Netherlands
}

Received: 16 December 2010 - Published in Clim. Past Discuss.: 21 December 2010

Revised: 24 October 2011 - Accepted: 29 October 2011 - Published: 8 December 2011

\begin{abstract}
The oxygen isotopic composition of planktonic foraminifera tests is one of the widest used geochemical tools to reconstruct past changes of physical parameters of the upper ocean. It is common practice to analyze multiple individuals from a mono-specific population and assume that the outcome reflects a mean value of the environmental conditions during calcification of the analyzed individuals. Here we present the oxygen isotope composition of individual specimens of the surface-dwelling species Globigerinoides ruber and Globigerina bulloides from sediment cores in the Western Arabian Sea off Somalia, inferred as indicators of past seasonal ranges in temperature. Combining the $\delta^{18} \mathrm{O}$ measurements of individual specimens to obtain temperature ranges with $\mathrm{Mg} / \mathrm{Ca}$ based mean calcification temperatures allows us to reconstruct temperature extrema. Our results indicate that over the past $20 \mathrm{kyr}$ the seasonal temperature range has fluctuated from its present value of $16^{\circ} \mathrm{C}$ to mean values of $13^{\circ} \mathrm{C}$ and $11^{\circ} \mathrm{C}$ for the Holocene and LGM, respectively. The data for the LGM suggest that the maximum temperature was lower, whilst minimum temperature remained approximately constant. The rather minor variability in lowest summer temperatures during the LGM suggests roughly constant summer monsoon intensity, while upwelling-induced productivity was lowered.
\end{abstract}

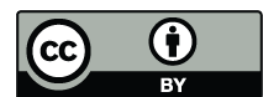

Correspondence to: G. M. Ganssen (g.m.ganssen@vu.nl)

\section{Introduction}

Since Cesare Emiliani's paper (1955) "Pleistocene Temperatures" indicated that the stable oxygen isotope ratio in the tests of foraminifera could be used to infer the temperature during calcification, the $\delta^{18} \mathrm{O}$ of planktonic foraminifera is one of the most applied methods for reconstructing past ocean temperature changes. Various geochemical methods used on marine archives have been applied since, including the $\mathrm{Mg} / \mathrm{Ca}$ ratio of the foraminiferal calcite (e.g. Nürnberg et al., 1996; Elderfield and Ganssen, 2000; Lea et al., 1999), the alkenone-based temperatures (Prahl and Wakeman, 1987) and $\mathrm{TEX}_{86}$ (Schouten et al., 2002) on organic material. To date, the simultaneous use of different proxies, referred to as a multi-proxy approach, is generally accepted to result in the highest possible accuracy and precision for reconstructing past ocean surface-water temperatures. Multi-proxy reconstructions, however, require sufficient and well-suited material from an oceanic setting, where the different signal carriers (reflecting the ocean conditions) are indeed produced and transported simultaneously to the sea-floor to form the archive.

The interpretation of the oxygen isotope composition of planktonic foraminifera $\left(\delta^{18} \mathrm{O}_{\mathrm{c}}\right)$ in terms of temperature variation is not straightforward, as the signal is determined by both temperature and the oxygen isotope composition of seawater $\left(\delta^{18} \mathrm{O}_{\mathrm{w}}\right)$ in which they calcify. Furthermore, these shells may secrete their calcite tests at different depths in the water column (Emiliani, 1954) and seasons of the

Published by Copernicus Publications on behalf of the European Geosciences Union. 
year (Hemleben et al., 1989). Conventional isotope analysis is based upon a number of specimens of planktonic foraminifera, typically ten to fifty, to obtain a mean isotope value for the selected population. The resulting value may include specimens having formed their calcite at various depths and seasons; hence, the conventional stable isotope data does not reflect the full range of $\delta^{18} \mathrm{O}_{\mathrm{c}}$ and resulting temperature.

Recent technological improvements in Isotope Ratio Mass Spectrometry allow measurements of small quantities of calcium-carbonate down to $\sim 5 \mu \mathrm{g}$, including individual specimen analyses of planktonic foraminifera.

In the first application of individual specimen analyses, Killingley et al. (1981) focused on the isotopic variability of Orbulina universa, Globigerinoides conglobatus and Globorotalia tumida from the equatorial Pacific. They interpreted this variation as a result of changes in temperature, salinity, depth habitat and seasonal and inter-annual variations as of metabolic effects. Attempts to determine the influence of size, and therefore growth (Spero and Williams, $1990)$, on the oxygen isotopic signal of test calcite $\left(\delta^{18} \mathrm{O}_{\mathrm{c}}\right)$ of Orbulina universa from the Orca Basin during the Late Pleistocene revealed no obvious relationship. The variability range from 2.08 to $5.31 \%$ was explained by temperature and salinity changes of the deglacial meltwater. Oba (1990) interpreted the isotope differences in Globigerinoides sacculifer of up to $2.8 \%$ in sediment trap samples from northwest Pacific Ocean as a reflection of the temperatures of the vertical calcification range for this species $(50-200 \mathrm{~m})$. He further assigned the depth habitat of eleven species based on single specimen analyses (Oba, 1991). Based on single specimen analyses of G. sacculifer, Globigerinoides ruber, Globigerinella aequilateralis, Globorotalia inflata, and $O$. universe, Tang and Stott (1993) reconstructed seasonal and inter-annual low salinity conditions of the eastern Mediterranean during sapropel S1. Using G. ruber and G. sacculifer from equatorial Atlantic box cores (Stott and Tang, 1996), they concluded that the effect of bioturbation on the Glacial/Holocene $\delta^{18} \mathrm{O}$ change is relatively minor, when 25 or more individual specimens are combined in a conventional stable isotope analysis. Reduced variance in single specimen isotope data of $G$. ruber as monthly recorders of ocean surface conditions near Galapagos Islands were interpreted as a drastic attenuation of the ENSO amplitude during the mid-Holocene (Koutavas et al., 2006). The analysis of individual shells of Neoloboquadrina dutertrei by Leduc et al. (2009) in the equatorial Pacific reveals the variability of ENSO activities during the past $50 \mathrm{kyr}$. Attempting to unravel seasonality in sea-surface temperatures, Wit et al. (2010) used paired single specimen oxygen isotope and $\mathrm{Mg} / \mathrm{Ca}$ analyses on $G$. ruber, concluding that other parameters than temperature affect these proxies.

In order to assess the potential of our single specimen approach, we first apply this method on modern sediment samples and then on core NIOP 905 from the Arabian Sea off Somalia. Sediments from this region record seasonal ("monsoonal") change through time. Previous studies implied that monsoonal circulation in the region systematically varied on orbital to sub-centennial time scales (e.g. Ivanochko et al., 2005; Jung et al., 2002; Clemens et al., 1991). Within the framework of this existing knowledge, our new single specimen data are used to illuminate aspects of change in monsoon circulation not yet addressed.

\section{Approach, material and methods}

Highest seasonal temperature change in the tropics are presently found off Somalia: During late winter and spring, temperatures higher than $30^{\circ} \mathrm{C}$ prevail, yet during the upwelling season, sea-surface temperatures may drop down to $16^{\circ} \mathrm{C}$ (Swallow and Bruce, 1966). This high seasonal amplitude in surface water temperatures of $>14^{\circ} \mathrm{C}$, together with only minor variability in salinity $(<0.5 \mathrm{PSU})$ and $\delta^{18} \mathrm{O}_{\mathrm{w}}$ $(<0.1 \%$ o $)$ in the upper $200 \mathrm{~m}$ of the water-column, makes the ideal setting to evaluate the potential of single specimen analyses of planktonic foraminifera to reflect the modern temperature range. Our estimate of salinity variation is based on CTD profiles taken at the time of the sediment coring (see Supplement). We performed single specimen analyses of G. ruber and Globigerina bulloides from a depth transect and a piston-core off Somalia (Fig. 1) in the western Arabian Sea (Ganssen et al., 2005). Studies conducted on depthstratified plankton tows and sediment traps in this region show that both species calcify predominantly in the upper $50 \mathrm{~m}$ of the water column (Peeters et al., 2002). While G. ruber is more or less continuously present throughout the year, G. bulloides predominantly grows during May to October (SW monsoon), when upwelling conditions prevail (Kroon and Ganssen, 1989; Conan and Brummer, 2000; Peeters and Brummer, 2002).

Analysis was performed on single shells from a restricted size-range of 355-400 $\mu \mathrm{m}$ for $G$. ruber and $300-355 \mu \mathrm{m}$ for G. bulloides from surface sediments $(0-1 \mathrm{~cm}$, box cores $902-$ 907, Fig. 1). Water depths range from $459 \mathrm{~m}$ to $2807 \mathrm{~m}$. Due to the high (seasonal) productivity caused by intense coastal upwelling, sedimentation rate along the sampled transect is between 20 and $40 \mathrm{~cm} \mathrm{kyr}^{-1}$, with mean surface sediment calendar ages between modern and $300 \mathrm{yr}$ BP (de Moel et al., 2009, Table 1).

The lysocline, according to the definition of Berger (1971), is the visible alteration of the foraminiferal assemblage composition, an increase in dissolution-resistant species, is observed between station 906 and 907 (Ivanova, 2000). Slight dissolution effects are indeed detectable on the fauna from core 907 . To avoid any bias of the geochemical data by dissolution, we excluded core 907 from further analyses.

The age model for piston core 905 is based on 24 radiocarbon dates between 0 and $35 \mathrm{kyr}$ (Ivanochko et al., 2005). The conversion from AMS ${ }^{14} \mathrm{C}$ dates to calendar ages of samples 25000 yrs and younger was done using Calib 4.4 (Stuiver et 


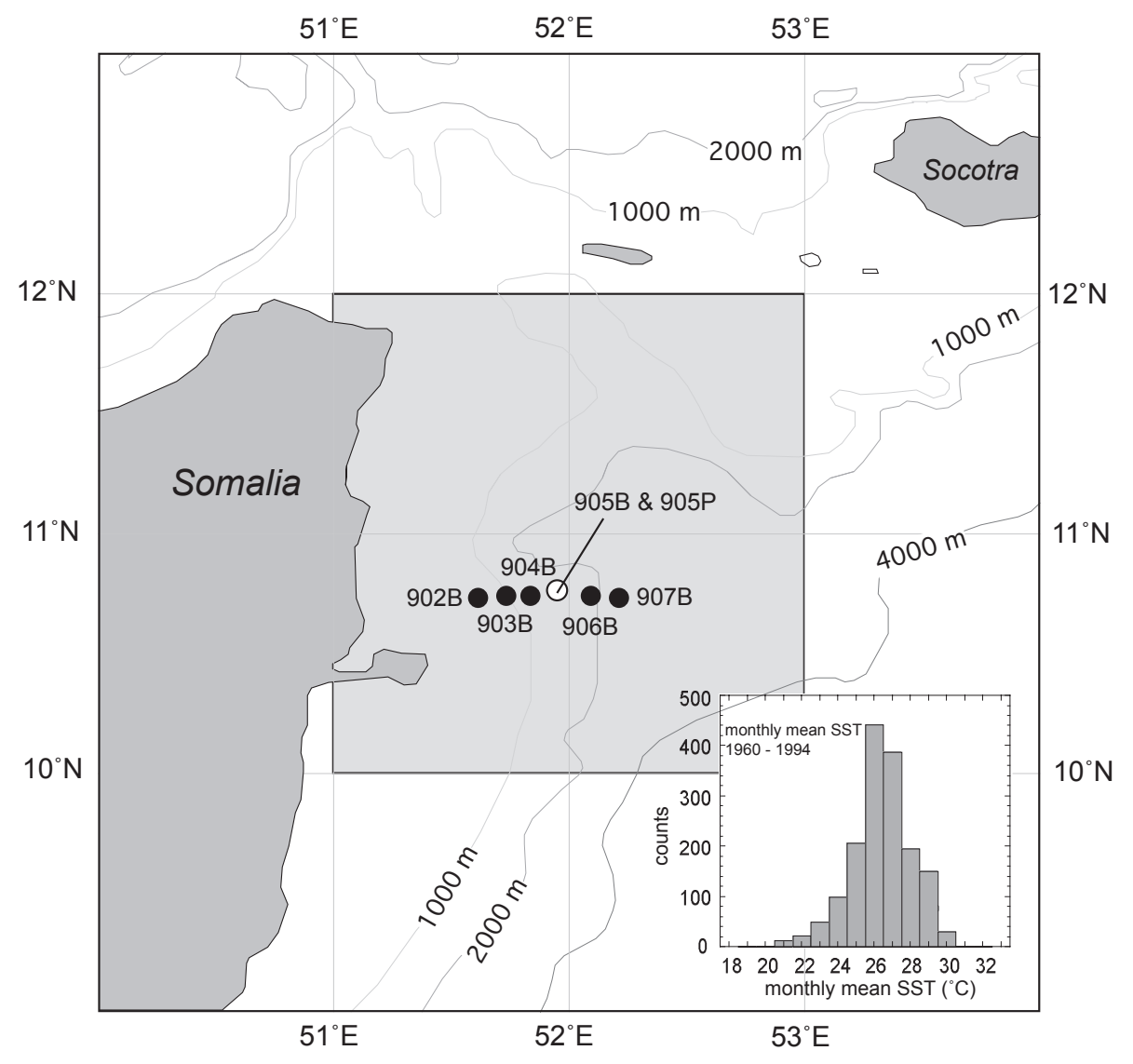

Fig. 1. Core locations of box cores 902 to 907 and piston core $905 \mathrm{P}$. The histogram shows the distribution of modern monthly mean sea surface temperatures from the area indicated in grey. The modern temperatures used for the validation of the approach are monthly mean sea-surface temperatures between 1960 and 1994 (1993 was the year of the sediment sampling). Please note that temperatures range from 18.8 to $33.0^{\circ} \mathrm{C}$.

al., 1998). Bioturbation depth is calculated at $15 \mathrm{~cm}$ for one of the cores along the transect (core 905) by means of ${ }^{210} \mathrm{~Pb}$ (de Moel et al., 2009). Only well-preserved shells with identical morphology were picked for geochemical analysis.

Whilst we have a high resolution age model, our relatively low sampling resolution means that we cannot be entirely sure about the leads and lags of individual events. We therefore offer a tentative analysis of the potential climatic impacts and their age assignation (see Fig. 3).

Stable isotope analyses were performed on single specimens of the two species using a Finnigan MAT252 mass spectrometer coupled to a Finnigan (Kiel-II type) preparation device. External reproducibility of a carbonate laboratory standard in the weight range $(8-20 \mu \mathrm{g})$ of a single specimen is $0.15 \%$ o $(1 \sigma)$ for $\delta^{18} \mathrm{O}$. For each sample along the transect, analysis was performed on between 30 and 40 individual specimen for both species.

For conversion of oxygen isotope values to temperatures, we used the equation of Kim and O'Neill (1997):

$T=16.1-4.64 \times\left(\delta_{\mathrm{c}}-\delta_{\mathrm{w}}\right)+0.09 \times\left(\delta_{\mathrm{c}}-\delta_{\mathrm{w}}\right)^{2}$ where $\delta_{\mathrm{c}}$ and $\delta_{\mathrm{w}}$ are the oxygen isotope values of the foraminifera and the water, respectively.

Changes in the evaporation/precipitation balance could potentially cause changes in $\delta^{18} \mathrm{O}_{\mathrm{w}}$. However, these additional changes are considered to be negligible by Delaygue et al. (2001), who utilise new observations combined with modeling results to improve the understanding of the modern $\delta^{18} \mathrm{O}$ - salinity relationship in the northern Indian Ocean. Using atmospheric fluxes corresponding to Last Glacial Maximum (LGM) conditions in a multibox model, the authors conclude that there was no important change within the $\delta^{18} \mathrm{O}$ - salinity relationship during this period compared to the present. Lewis et al. (2010) performed model studies of the impact of water vapour source on oxygen isotope variability in precipitation. They conclude for coastal and tropical areas associated with the ITCZ rain that isotopic variability likely reflects local rainfall intensity changes by the so-called 'amount effect'. Based on a speleothem (Moomi Cave) $\delta^{18} \mathrm{O}$ record from the island of Socotra, about 150 miles from our coring sites, Shakun et al. (2007) reconstruct variation in the $\delta^{18} \mathrm{O}$ record of more than $2 \%$ o during the last deglaciation. 
Table 1. Water depth and position of the sediment cores. Radiocarbon dates (where available) of the upper $1 \mathrm{~cm}$ performed on surfacedwelling foraminifera. Calendar ages were obtained after reservoir age correction of 800 years.

\begin{tabular}{lrllll}
\hline $\begin{array}{l}\text { box } \\
\text { cores }\end{array}$ & $\begin{array}{r}\text { water } \\
\text { depth } \\
(\mathrm{m})\end{array}$ & latitude & longitude & ${ }^{14} \mathrm{C}$ age & $\begin{array}{l}\text { calendar } \\
\text { age } \\
(\mathrm{yr} \mathrm{BP})\end{array}$ \\
\hline $902 \mathrm{~B}$ & 459 & $10^{\circ} 46.72^{\prime}$ & $51^{\circ} 34.64^{\prime}$ & 768 & modern \\
$903 \mathrm{~B}$ & 789 & $10^{\circ} 46.97^{\prime}$ & $51^{\circ} 39.48^{\prime}$ & & \\
$904 \mathrm{~B}$ & 1194 & $10^{\circ} 47.27^{\prime}$ & $51^{\circ} 46.23^{\prime}$ & & \\
$905 \mathrm{~B}$ & 1567 & $10^{\circ} 54.94^{\prime}$ & $51^{\circ} 56.65^{\prime}$ & 327 & modern \\
$906 \mathrm{~B}$ & 2020 & $10^{\circ} 48.70^{\prime}$ & $52^{\circ} 07.76^{\prime}$ & & \\
$907 \mathrm{~B}$ & 2807 & $10^{\circ} 48.24^{\prime}$ & $52^{\circ} 14.96^{\prime}$ & -24 & modern \\
\hline piston core & & & & & \\
\hline $905 \mathrm{P}$ & 1586 & $10^{\circ} 46.01^{\prime}$ & $51^{\circ} 57.04^{\prime}$ & 980 & $198-123$ \\
\hline
\end{tabular}

About $70 \%$ of the amplitude was explained by the amount effect, with more negative values corresponding to greater rainfall. Hence, strong changes in the amount of precipitation in our core site area could potentially change the isotopic composition of sea-water. However, the amount of annual rainfall today is $100 \mathrm{~mm}$ (based on the satellite data used by Shakun et al., 2007), with a maximum of $30 \%$ within one month. If we assume an increase of rainfall by a factor of 10 (maximum of $30 \mathrm{~cm}$ within a month, which is unrealistically high) and an isotopic composition of the rainwater with 1$2 \%{ }^{18} \mathrm{O}$ depleted values, the surface ocean water would get depleted for the period of extremely heavy rainfall in the order of a few tenths of a permil. These events of heavy rainfall would occur mainly during the SW-monsoon months where strong winds would cause next to rapid mixing in the upper ocean strong upwelling of subsurface, colder waters. These lowered temperatures would cause enrichment of ${ }^{18} \mathrm{O}$ during calcification of foraminifera shells, hence the opposite effect than the potentially lighter water isotopes would have on the calcite shells. We thus regard additional effects of $\delta^{18} \mathrm{O}_{\mathrm{w}}$ to be minimal, and the $\delta^{18} \mathrm{O}$ variability of foraminifera in the studied region to be caused mainly by temperature and the glacial effect.

Analysis of 24 surface water samples (Table 3) covering the transect was performed on the same mass spectrometer coupled to a Finnigan MAT water equilibration unit with a reproducibility of $0.1 \% \circ(1 \sigma)$. The mean value is $0.25 \pm 0.08 \%$ (V-SMOW). Conversion from V-SMOW to V-PDB follows Hut (1987). Temperature data derived from $\mathrm{Mg} / \mathrm{Ca}$ ratios of the two species are based on about 30 specimens in the fractions $250-300 \mu \mathrm{m}$. The foraminiferal samples were gently crushed under glass plates and homogenized for $\mathrm{Mg} / \mathrm{Ca}$ measurement. Samples for $\mathrm{Mg} / \mathrm{Ca}$ analyses were chemically cleaned using the method of Barker et al. (2003) before analysis by ICP-AES (de Villiers et al., 2002).
Temperature estimates based on $\mathrm{Mg} / \mathrm{Ca}$ of $\mathrm{G}$. ruber and G. bulloides were obtained using species-specific equations obtained from Atlantic sediment trap and core top calibrations (Anand et al., 2003; Elderfield and Ganssen, 2000). The $\mathrm{Mg} / \mathrm{Ca}$-temperature equations used in this study are

$T=(1 / 0.09) \times \mathrm{LN}(\mathrm{Mg} / \mathrm{Ca} / 0.449)$

(see Anand et al., 2003 for G. ruber) and

$T=(1 / 0.102) \times \mathrm{LN}(\mathrm{Mg} / \mathrm{Ca} / 0.528)$

(see Elderfield and Ganssen, 2000 for G. bulloides).

The standard error associated with the $\mathrm{Mg} / \mathrm{Ca}$ - temperature calibration is $\pm 1.2^{\circ} \mathrm{C}$ (Anand et al., 2003). The analytical errors are significantly smaller compared to the standard error associated with the calibration error. At the time of analysis, precision of measured $\mathrm{Mg} / \mathrm{Ca}$ ratios was $<0.02 \mathrm{mmol} \mathrm{mol}^{-1}(1 \sigma$ s.d. $)$ for a standard solution of $\mathrm{Mg} / \mathrm{Ca}=5.13 \mathrm{mmol} \mathrm{mol}^{-1}$ (Anand et al., 2008), which is equivalent to $\sim 0.06^{\circ} \mathrm{C}$ using the species specific $\mathrm{Mg} / \mathrm{Ca}-\mathrm{T}$ calibration for G. ruber. The utilization of different size fractions for stable isotope and $\mathrm{Mg} / \mathrm{Ca}$ analysis has no significant effect on the established temperature (Table 2). The observable decrease in the $\mathrm{Mg} / \mathrm{Ca}$ ratio with increasing water depth and distance from the coast is related to the position of the upwelling cell, which is centered at the position of core 905 where highest productivity as shown by $\%$ organic carbon (Ivanova, 1999) and highest oxygen isotope values (lowest temperatures) coincide.

The modern temperatures used for the validation of our approach are monthly mean sea-surface temperatures constrained between 1960 and 1993, the year of the initial instrumental recording and sediment sampling, and derive from four $1 \times 1^{\circ}$ grids which cover the sampling area (http://www. ncdc.noaa.gov/oa/climate/research/sst/sst.php) (Fig. 1). For more detailed modern temperature data we refer to the Supplement.

Temperature ranges were obtained as follows:

1. The $\delta^{18} \mathrm{O}$ measurements performed on single shells are evaluated for potential outliers. Since we consider our present dataset too small to conclude that $\delta^{18} \mathrm{O}$ data of singe shells are normally distributed, we used a method that identifies outliers based on the inter-quartile range (IQR) for each $\delta^{18} \mathrm{O}$ data set. This means we define a measurement to be an outlier if it falls outside the range $[Q 1-1.5(Q 3-Q 1), Q 3+1.5(Q 3-Q 1)]$, with $Q 3$ and $Q 1$ being the third and first quartile of the data and $\mathrm{IQR}=Q 3-Q 1$.

2. $\mathrm{The} \mathrm{Mg} / \mathrm{Ca}$ - calcification temperature then is used to anchor the mean $\delta^{18} \mathrm{O}$ value. Since the $\mathrm{Mg} / \mathrm{Ca}$ calcification temperatures is based on about 30 specimens it is considered to mirror mean calcification temperature of the fossil population. 


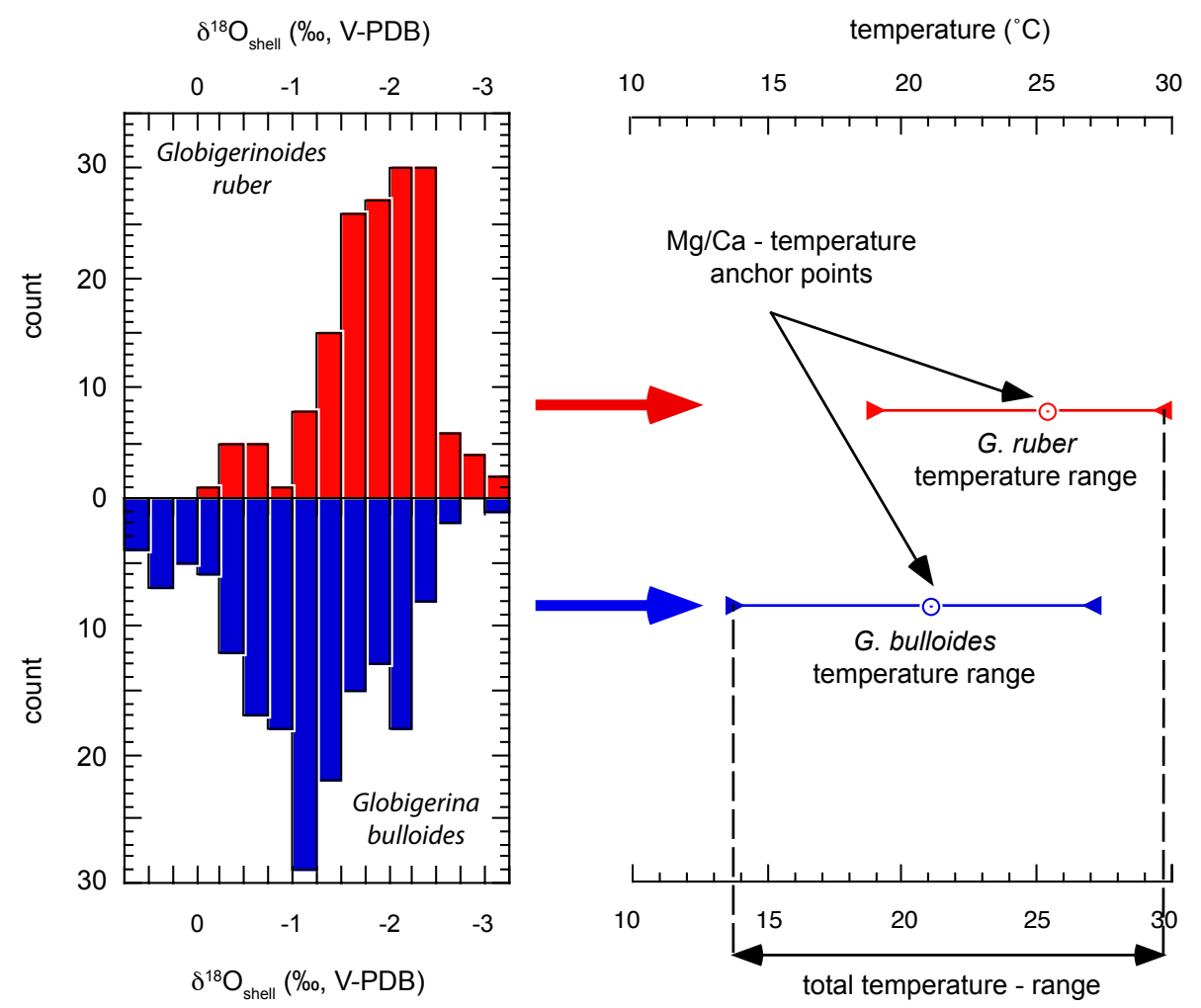

Fig. 2. Oxygen isotope data from all boxcores (902-906) for G. ruber $(n=160)$ and G. bulloides $(n=177)$ plotted in $0.25 \%$ wide bins (left panel) and inferred calcification temperature ranges for both species (right panel). Open dots are the mean temperatures derived from the $\mathrm{Mg} / \mathrm{Ca}$ analysis of surface sediments from the same cores; the lines indicate the total range of calcification temperatures obtained for each species with the most extreme values indicated by triangles.

3. Temperature extrema are calculated by using the maximum and minimum $\delta^{18} \mathrm{O}$ values obtained for each species: the maximum calcification temperature is obtained from $T_{\mathrm{Mg} / \mathrm{Ca}}+\left(\delta^{18} \mathrm{O}\right.$ minimum $-\delta^{18} \mathrm{O}$ average $) /-0.22$ and the minimum temperature as $T_{\mathrm{Mg} / \mathrm{Ca}}-\left(\delta^{18} \mathrm{O}\right.$ maximum $-\delta^{18} \mathrm{O}$ average $) /-0.22$.

4. The total range of calcification temperatures is calculated by subtracting the highest temperature of the warmest species from the lowest temperature of the coldest species. In case the species are known to have an offset from SST, a correction factor may be applied to convert the calcification temperature range to SST range. Peeters et al. (2002) concluded that the calcification temperature indeed is 1.7 and $1.3{ }^{\circ} \mathrm{C}$ lower than SST for G. ruber and G. bulloides, respectively.

\section{Modern temperatures and validation of approach}

The observed ranges in oxygen isotope data from the individual specimens are equivalent to temperature ranges of about $13^{\circ} \mathrm{C}$ for G. bulloides and $11^{\circ} \mathrm{C}$ for G. ruber (Fig. 2). The relatively small calcification temperature range of $G$. ruber indicates that this species does not calcify during the coldest conditions as its lowest temperature tolerance limit is reached. The minimum temperature where $G$. ruber calcifies is at around $16^{\circ} \mathrm{C}$ (Hemleben et al., 1989). In our record, G. ruber does not show temperatures lower than $18^{\circ} \mathrm{C}$, see also Fig. 4, right panel. G. bulloides appears to be primarily controlled by variation in primary productivity rather than by temperature (Hemleben et al., 1989) and has a temperature range form $0-27^{\circ} \mathrm{C}$ (Bé and Tolderlund, 1971). The total range for both species of $16^{\circ} \mathrm{C}$ is approximately $2{ }^{\circ} \mathrm{C}$ higher than the observed modern range (Fig. 1, see also Supplement), which can be explained by the fact that modern observations represent monthly averaged temperatures over a period of 34 years, thus excluding extreme temperatures that may have occurred in the region during periods of less than a month. The two species have a life cycle of between a few weeks to a month (Bijma et al., 1994; Loncaric et al., 2005) with a single chamber formed within a few hours (Bé et al., 1977), thereby registering short-lasting, extreme temperatures within their skeletons. This might apply especially for the low temperature end, where sporadically extreme cold upwelling events (Swallow and Bruce, 1966) are averaged out of published monthly mean temperature records but might be registered when one or several chambers of a 


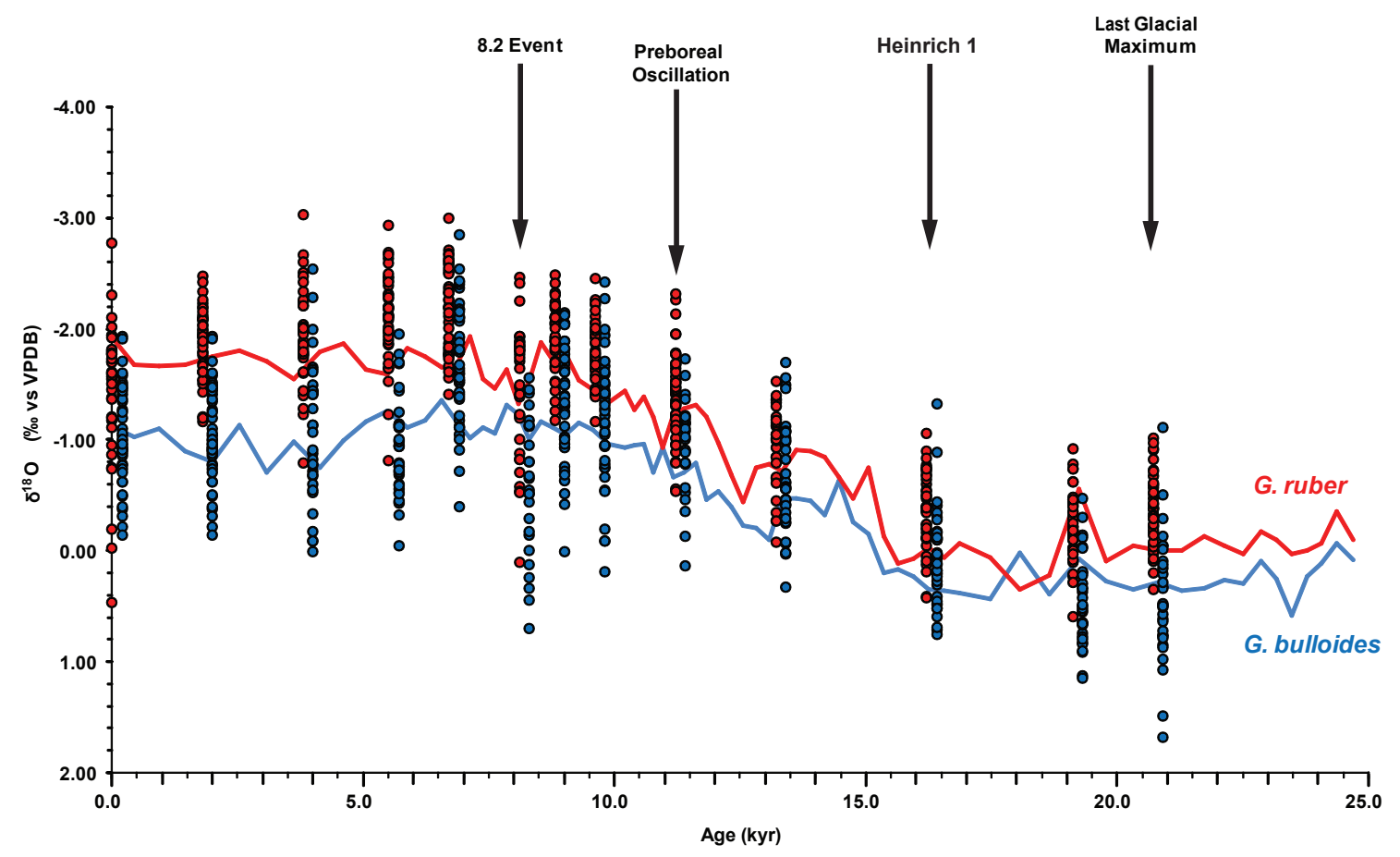

Fig. 3. Oxygen isotopes of G. ruber (red circles) and G. bulloides (blue circles) using individual specimen analysis against conventional isotope analysis (lines) from Ivanova (2000). Labels indicate key events outlined in text; note that G. bulloides single specimen data is offset by $0.2 \mathrm{kyr}$ from $G$. ruber data in order to aid visibility. The dataset represents uncorrected values.

specimen are formed. The modern observational data set is restricted to the upper $5 \mathrm{~m}$, whilst the signals registered in foraminiferal calcite are indicative of the upper $50 \mathrm{~m}$ of the water column (Peeters et al., 2002).

Prior analysis using conventional methods suggest that there is minimum variability from both species $(<0.3 \%)$ along the transect (unpublished data).

The mean oxygen isotope values from all box-cores for G. ruber and G. bulloides give temperatures of $25.0^{\circ} \mathrm{C}$ and $21.7^{\circ} \mathrm{C}$ (Eq. 1), respectively, and compare well with the mean temperatures obtained by $\mathrm{Mg} / \mathrm{Ca}$ analysis (Anand et al., 2008, Fig. 2) of the two species in the fraction 250$300 \mu \mathrm{m}$ from the same box-core transect: $25.4^{\circ} \mathrm{C}$ for $\mathrm{G}$. ruber and $21.2^{\circ} \mathrm{C}$ for $G$. bulloides. This finding justifies the use of the $\mathrm{Mg} / \mathrm{Ca}$ temperatures as an anchor point for the mean $\delta^{18} \mathrm{O}$ values based on the single specimen analyses.

The combination of the two geochemical methods $(\mathrm{Mg} / \mathrm{Ca}$ and $\delta^{18} \mathrm{O}$ ) results in an error of $1.1^{\circ} \mathrm{C}$ on the upper and the lower temperature estimation (see Supplement). However, we consider the error of about $2{ }^{\circ} \mathrm{C}$ for the total range based on a total of 60 to 80 measurements to be acceptable, considering the conventional methods rely on a single measurement.

\section{Seasonality during the past 20000 years}

\subsection{Results}

To reconstruct past environmental conditions focusing on seasonal change, we applied the single specimen approach on two planktonic foraminifera species (G. ruber and G. bulloides) from twelve, mostly equally-spaced samples from sediment core NIOP 905P (Fig. 3). Sediment core NIOP 905 is located off Somalia, below the modern upwelling center. This sediment sequence has been intensely studied before (Ivanova, 2000; Ivanochko et al., 2005; Jung et al., $2002,2004,2009,2011)$ allowing to precisely date the lowresolution sample set used in this study. Accordingly, we are able to reconstruct changes of sea-surface temperature ranges over the past $20 \mathrm{kyr}$ (Fig. 4). The time equivalent of each $1 \mathrm{~cm}$ sample according to the age model (Ivanochko et al., 2005 ) is less than 100 years and the gaps between samples range between 800 and 2900 years. The average values from the individual measurements from a restricted size-range of $355-400 \mu \mathrm{m}$ for G. ruber and 300-355 $\mu \mathrm{m}$ for G. bulloides are partly different from the earlier established data (Fig. 3), probably an artifact of different methodology. The traditional or bulk isotope analysis is a summation of the variance within a foraminiferal population, as much as each individual shell value is the product of depth integrated growth. The difference between mean values is potentially the result of the 


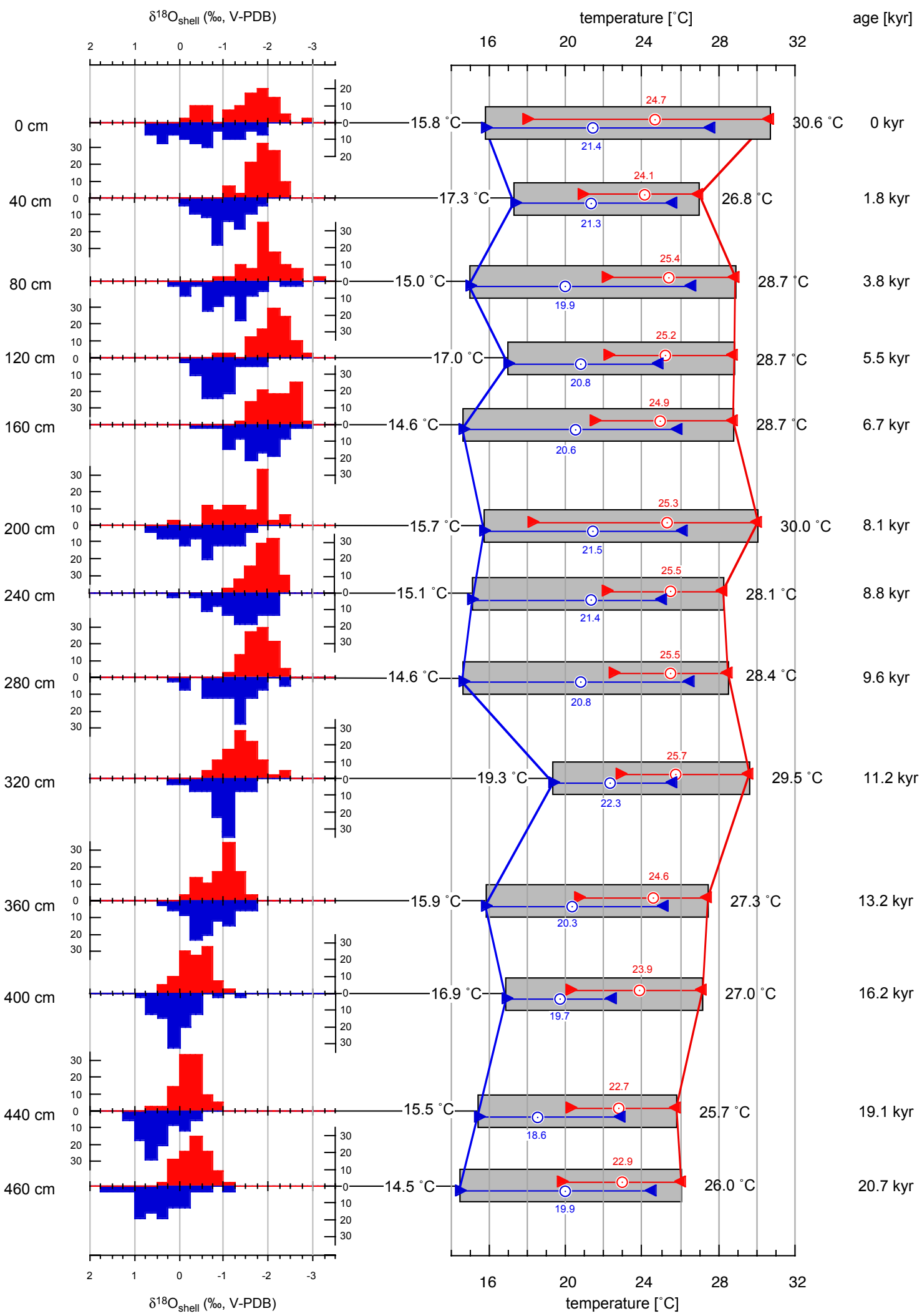

Fig. 4. Oxygen isotope data for piston core 905P G. ruber (in red) and G. bulloides (in blue) plotted in $0.25 \%$ wide bins in \% (left panel). Inferred calcification temperature ranges for both species (right panel). Open dots are the mean temperatures derived from the $\mathrm{Mg} / \mathrm{Ca}$ analysis for both species of the respective samples, the lines indicate the total range of calcification temperatures obtained for each species with the most extreme values indicated by triangles. 
Table 2a. $\mathrm{Mg} / \mathrm{Ca}$ data for $\mathrm{G}$. ruber in three different size fractions.

\begin{tabular}{lrrlc}
\hline $\begin{array}{l}\text { fraction } \\
(\mu \mathrm{m})\end{array}$ & site & $\begin{array}{r}\text { water } \\
\text { depth } \\
(\mathrm{m})\end{array}$ & $\begin{array}{l}\mathrm{Mg} / \mathrm{Ca} \mathrm{ratio} \\
\left(\mathrm{mmol} \mathrm{mol}^{-1}\right)\end{array}$ & $\begin{array}{c}\mathrm{Mg} / \mathrm{Ca}- \\
\text { temperature } \\
\left({ }^{\circ} \mathrm{C}\right)\end{array}$ \\
\hline $250-300$ & 902 & 459 & 4.67 & 26.02 \\
& 903 & 789 & 4.54 & 25.71 \\
& 904 & 1194 & 4.62 & 25.90 \\
& 905 & 1567 & 4.15 & 24.71 \\
& 906 & 2020 & 4.06 & 24.47 \\
& 907 & 2807 & 4.51 & 25.63 \\
& & & & mean 25.40 \\
\hline $300-355$ & 902 & 459 & 4.81 & 26.36 \\
& 903 & 789 & 4.81 & 26.35 \\
& 904 & 1194 & 5.11 & 27.03 \\
& 905 & 1567 & 4.55 & 25.73 \\
& 906 & 2020 & 4.33 & 25.25 \\
& 907 & 2807 & 4.36 & mean 25.98 \\
\hline $355-425$ & 902 & 459 & 4.99 & 26.76 \\
& 903 & 789 & 5.05 & 26.90 \\
& 904 & 1194 & 4.42 & 25.41 \\
& 905 & 1567 & 4.50 & 25.62 \\
& 906 & 2020 & 4.26 & 24.28 \\
& 907 & 2807 & 3.99 & \\
& & & & \\
\hline
\end{tabular}

Table 2b. Oxygen isotopes of G. ruber in two different size fractions from core $905 \mathrm{~B}, 0-1 \mathrm{~cm}$.

\begin{tabular}{ll}
\hline G. ruber $355-400 \mu \mathrm{m}$ & G. ruber $300-355 \mu \mathrm{m}$ \\
\hline$\delta^{18} \mathrm{O}(\% \circ \mathrm{V}-\mathrm{PDB})$ & $\delta^{18} \mathrm{O}(\% \circ \mathrm{V}-\mathrm{PDB})$ \\
mean: $-1.50, n=40$ & mean: $-1.47, n=35$ \\
\hline
\end{tabular}

various individual shells providing a varying amount of calcite to the overall signal due to the range in shell weight. In addition, while for our study 30 to 40 specimens were measured individually, the isotope curves for G. ruber and G. bulloides in Fig. 3 are based on measurements of 8-10 and 1417 specimens, respectively, in the size fraction $250-350 \mu \mathrm{m}$ (Ivanova, 2000). This observation stresses the importance of using a sufficient amount of individuals for conventional isotope analysis if a representative mean value from a population is aimed to be established.

We realize, however, that the reconstructed extremes (maximum and minimum calcification temperatures, Fig. 4) approach but do not perfectly reflect the maximum and minimum SSTs. It is unlikely that the $\delta^{18} \mathrm{O}$ of the foraminifera did indeed record the most extreme SST values, since the duration and frequency of such events could be relatively short compared to the length of time represented within each sample (likely in the order of a number of decades). As the composite range of calcification temperature depends on the
Table 3. Salinity and oxygen isotope composition of surface waters in the research area, measured and sampled in June 1992.

\begin{tabular}{rccc}
\hline latitude & longitude & salinity psu & $\delta^{18} \mathrm{O}(\%$ o V-SMOW $)$ \\
\hline 12.30 & 49.50 & 35.79 & 0.20 \\
12.40 & 50.60 & 35.77 & 0.21 \\
12.20 & 51.70 & 36.14 & 0.26 \\
12.00 & 52.40 & 35.63 & 0.17 \\
11.50 & 53.00 & 35.56 & 0.20 \\
10.90 & 53.40 & 35.48 & 0.21 \\
10.70 & 53.60 & 35.45 & 0.26 \\
10.80 & 53.20 & 35.50 & 0.15 \\
11.20 & 52.20 & 35.68 & 0.19 \\
11.30 & 51.90 & 35.83 & 0.39 \\
10.90 & 51.80 & 35.81 & 0.35 \\
10.80 & 52.00 & 35.72 & 0.28 \\
10.70 & 52.40 & 35.47 & 0.31 \\
10.80 & 51.90 & 35.72 & 0.26 \\
10.80 & 51.90 & 35.72 & 0.29 \\
10.80 & 52.10 & 35.55 & 0.19 \\
10.80 & 52.00 & 35.57 & 0.27 \\
10.80 & 51.90 & no data & 0.28 \\
10.70 & 52.40 & no data & 0.04 \\
10.70 & 53.10 & no data & 0.30 \\
10.90 & 53.60 & no data & 0.22 \\
10.30 & 53.00 & no data & 0.34 \\
9.89 & 52.30 & no data & 0.33 \\
9.39 & 51.90 & no data & 0.34 \\
\hline & & mean & 0.25 \\
& & & \pm 0.08 \\
\hline & & &
\end{tabular}

number of oxygen isotope measurements, an increase of this range can be expected with increasing number of measurements, up to a point. As in practice only a limited number of measurements is feasible, the range of the individual measurements can thus only approach the extremes in seasonal temperature for the time period represented by the sediment sample. However, a shift within the mean temperatures to either hotter or colder climate will likely increase the probability of an occurrence in the single specimen record.

The cumulative plots of the individual measurements (Fig. 4, left panel) show a wide range in oxygen isotope values for both species, with generally lower (warmer) values for G. ruber compared to G. bulloides. The generally higher stable oxygen isotope values in both species from samples below $360 \mathrm{~cm}$ (13.2 ka BP) reflect changes in global ice volume. Traditionally, stable oxygen isotope values require correction for changes in global ice volume. We avoid this step by anchoring the stable oxygen isotope values using the $\mathrm{Mg} / \mathrm{Ca}$-based temperature estimates (see Methods section for more detailed information). Using this approach, the spread in stable oxygen isotope values in Fig. 4 (right panel) reflects variability in seasonal sea surface temperatures.

The seasonal temperature ranges during the Holocene (samples $0 \mathrm{~cm}$ down to $280 \mathrm{~cm}$, (Fig. 4, right panel) varies 
between 14.8 and $9.5^{\circ} \mathrm{C}$ with an average value of $13.1^{\circ} \mathrm{C}$, while the full range of temperatures covered during this period is $14.6-30.6^{\circ} \mathrm{C}$, resulting in the maximum temperature range of $16^{\circ} \mathrm{C}$ for the Holocene. Further down-core, the average temperature range is lower, with small seasonal temperature ranges of 10.2 and $10.1{ }^{\circ} \mathrm{C}$ occurring at 320 and $400 \mathrm{~cm}$ depth, respectively (Fig. 3). The average temperature range during the last glacial (samples taken at 440 and $460 \mathrm{~cm}$ ) is roughly $10.9^{\circ} \mathrm{C}$.

The differences in seasonal temperature ranges are mainly due to a decrease of the highest temperatures with mean values of $28.7^{\circ} \mathrm{C}$ during the Holocene compared to $\sim 25.8^{\circ} \mathrm{C}$ during the glacial. At the low temperature end, the data do not show any significant and systematic change during these time periods.

\subsection{Discussions}

Sea surface temperatures off Somalia are controlled by monsoonal airflow. SW-monsoon winds prevail during summer and induce upwelling of cold and nutrient-rich subsurface water off Somalia. The injected nutrients fuel high productivity levels at site NIOP 905 during this time of the year. During winter, atmospheric flow reverses with NE-monsoon winds, causing a largely stratified water column during the winter monsoon and the inter-monsoon seasons (transitional time periods between monsoon seasons).

The planktonic foraminifera species G. bulloides forms almost exclusively during summer upwelling (Conan and Brummer, 2000). Hence, using our approach the single specimen isotope data of $G$. bulloides used in this study reflect variations in sea surface temperatures occurring along with monsoon induced upwelling during summer. The planktonic foraminifera species G. ruber forms throughout the year, with moderate reproduction spikes centered on both monsoon seasons. Oxygen isotope data from G. ruber should mainly reflect variations in annual sea surface temperatures through time when mean values from isotope analysis of multiple specimens are considered. The top end of the temperature range recorded in the oxygen isotope data from single specimens of $G$. ruber probably reflects a mix of winter monsoon and inter-monsoon conditions, when highest seasonal sea surface temperatures prevail in this region. In the light of these considerations, the rather stable summer sea surface temperatures shown in Fig. 4 (with the exception of sample $320 \mathrm{~cm}$ ) support the view that $\mathrm{SW}$-monsoon driven upwelling did not vary substantially when comparing Holocene with full glacial conditions. Therefore, our new data show that the summer monsoon induced circulation off Somalia was rather constant during these intervals. Previously published geochemical data, however, combined with census data on key planktonic foraminifera species (Jung et al., 2002; Ivanova, 2000; Ivanochko et al., 2005), support the notion of subdued productivity prevailing around $20 \mathrm{kaBP}$ at site NIOP 905 when comparing full glacial - with modern/Holocene - conditions. Hence, whilst the rather minor variability in lowest summer temperatures suggests roughly constant summer monsoon intensity, the resulting productivity during the last glacial was lower. The most likely explanation for this discrepancy is a change in nutrient concentrations in the subsurface waters entrained in upwelling off Somalia. It is beyond the scope of the present work to engage in an in-depth discussion of productivity variations in the Arabian Sea through time. A full assessment of the wider implications of reductions in nutrient levels in upwelling waters in the glacial Arabian Sea off Somalia is deferred to a future paper. Nevertheless, this possibility to distinguish variations in physical properties from changes in seawater chemistry at the seasonal level is new and may help to improve our understanding of the process controlling climate change.

With increasing availability of high-quality records from key areas in the Arabian Sea, our finding adds to the growing understanding of the diverse change in surface ocean conditions having occurred in the LGM-time Arabian Sea. New results from the eastern Arabian Sea off Goa, for example, suggest that productivity in the region was substantially enhanced during the LGM (Singh et al., 2011). In the northern Arabian Sea, however, productivity was lower during the LGM (Anderson and Prell, 1993; Schulz et al., 1998). While off Goa, productivity is largely controlled by winter NE monsoon winds; further north and at site NIOP 905, productivity is largely governed by summer monsoonal airflow. Hence, with regards to lower productivity prevailing during the LGM in regions where productivity is controlled by summer monsoon winds, previously published data for core NIOP 905 concur with data from elsewhere. The wider significance of the proposed lowered nutrient concentrations in the subsurface Arabian Sea during the last glacial is difficult to assess in the absence of suitable data from the eastern Arabian Sea.

Based on existing high-resolution data from core NIOP 905 (Ivanochko et al., 2005), the samples taken at $320 \mathrm{~cm}$ and $400 \mathrm{~cm}$ correspond to the Preboreal Oscillation at the start of the Holocene and Heinrich Event 1, respectively. Interestingly, during both periods the seasonal temperature range was significantly reduced. At $320 \mathrm{~cm}(11.2 \mathrm{ka} \mathrm{BP})$, the reduction in the seasonal temperature gradient is solely due to a rise in summer sea surface temperatures (low temperature end), whereas high values found at the upper temperature end suggest Holocene-type conditions prevailing during inter- and winter-monsoon seasons. From a high resolution deglacial speleothem record from the island of Socotra, Shakun et al. (2007) provide evidence for an abrupt dry period at 11.2 ka BP during the Preborial Oscillation. This event is explained by decreased SW-monsoon winds as a result of a northward shift of the ITCZ. Such a scenario fully supports our interpretation of relatively high temperatures during the summer monsoon caused by reduced upwelling intensity as recorded in core 905 . 
Previous studies suggest that monsoonal circulation in the Arabian Sea substantially varied along with the well-known millennial-scale climate variability (Ivanochko et al., 2005; Jung et al., 2009; Jung and Kroon, 2011; Schulz et al., 1998; Wang et al., 2005; Singh et al., 2011). Our new findings are largely in line with these earlier results although the nature of our low-resolution data set prevents definitive statements at this stage. With regards to the change in monsoon intensity during Heinrich Event 1, for example, previous studies are in support of a significantly reduced SW-monsoon strength (Ivanochko et al., 2005; Schulz et al., 1998; Altabet et al., 2002; Singh et al., 2011; Shakun et al., 2007). A reduced summer monsoon circulation entails subdued upwelling intensity and higher sea surface temperatures in the region (Saher et al., 2007; Anand et al., 2008). The rise in summer sea surface temperatures in Fig. 4 is fully in line with these findings, indeed suggesting a reduction in summer monsoonal airflow.

It is interesting to note that new results from the eastern Arabian Sea imply that the winter monsoon strength was also reduced during Heinrich Event 1 (Singh et al., 2011). This finding contrasts with the classical view of a strengthened winter monsoon in the Arabian Sea during N-Atlantic cold events. The new data from the eastern Arabian Sea are, however, in line with our new data. If winter monsoon circulation had intensified during Heinrich Event 1, it should have affected sea surface temperatures off Somalia. Enhanced advection of cold NE-monsoon air masses would likely have led to a significant drop in temperatures off Somalia during winter. This suggests that highest sea surface temperatures may have occurred during the inter monsoon seasons. With regard to the latter, the maximum temperatures recorded in G. ruber were also lower during Heinrich Event 1 compared to the Holocene, supporting the notion of a year-round drop in sea surface temperatures. In this sense and adding intensified circulation of cold Heinrich-time NE-monsoon winds to the mix, average sea surface temperatures recorded by G. ruber should have dropped markedly. Given the seasonal distribution pattern of $G$. ruber, we believe that this is a rather robust conclusion even when factoring in a possible partial compensation of this drop by higher sea surface temperatures during the summer monsoon. Figure 4 lacks such a significant drop in temperature, pointing at no additional winter monsoon influence off Somalia during Heinrich Event 1.

Regarding the Preboreal Oscillation period, our results are largely in line with previously published data. Similar to the change occurring during Heinrich Event 1, summer monsoon circulation was reduced off Somalia. The higher summer temperatures shown in Fig. 4 indicate reduced upwelling strength. The reduction in summer monsoon circulation inferred from this finding also implies a reduced productivity at site NIOP 905 and other areas controlled by summer monsoon winds (Ivanochko et al., 2005; Schulz et al., 1998). At the high-temperature end, G. ruber reflects the highest mean temperatures in the $\mathrm{Mg} / \mathrm{Ca}$ record and the maximum temperature of $29.5^{\circ} \mathrm{C}$ is perfectly in line with the modern values. This suggests that at the start of the Holocene the change in monsoonal airflow was highly seasonal, i.e. a strong reduction in SW-monsoon strength contrasted by Holocene-like conditions during the NE-monsoon.

Our results also support existing evidence for the semiglobal nature of the " $8.2 \mathrm{ka}$ event" recorded within the Greenland Ice sheet as a reduction in ice accumulation and temperature change $3.3 \pm 1.1^{\circ} \mathrm{C}$ as well as a drop in atmospheric methane concentration (Alley et al., 1997; Kobashi et al., 2007). This event, a period of pronounced cooling ( $\sim 160$ years), is within the temporal resolution provided with the sampling resolution $\left(\sim 20 \mathrm{~cm} \mathrm{kyr}^{-1}\right)$. Enrichment of $\delta^{18} \mathrm{O}$ values of both G. bulloides and G. ruber (Fig. 4, left panel) indicates a potential change in E/P balance at $8.2 \mathrm{kaBP}$. More detailed archives conclude this period to be characterized by reduced precipitation (Wiersma and Renssen, 2006).

Interestingly, the smallest seasonal temperature range of less than $10^{\circ} \mathrm{C}$ is observed during the late Holocene at $1.8 \mathrm{kaBP}$. Here, both seasons are characterized by less extreme temperatures compared to the neighboring intervals, while the mean $\mathrm{Mg} / \mathrm{Ca}$ temperatures do not show a significant change. Within the limitations of the low-resolution sample set used in this study, this finding suggests that severe changes of seasonal extremes in temperature occur on the millennial to centennial time scale, while the mean temperatures of both seasons remain constant. Such a scenario is in line with rapid changes in Holocene surface ocean properties at site NIOP 905 reported earlier (Jung et al., 2002, 2004). A higher sampling resolution may show the seasonality characteristic for rapid climate change.

\section{Conclusions and outlook}

Our study demonstrates that the oxygen isotope composition of individual shells of G. ruber and G. bulloides from deepsea sediments off Somalia approaches the extreme seasonal temperature contrasts in the tropics caused by the West-Asian monsoon system. Seasonal temperature ranges differ for the last glacial $\left(11^{\circ} \mathrm{C}\right)$ compared to the Holocene $\left(13^{\circ} \mathrm{C}\right)$. At the start of the Holocene, the SW-monsoon was even weaker than during the last glacial, while the NW-monsoon operated already in its Holocene mode. Our approach enables us to reconstruct sea surface temperature maxima and minima, adding a new dimension to conventional reconstructions. Our findings suggest that severe changes of seasonal extremes in temperature occur on the millennial to centennial time scale, while the mean temperatures of both seasons remain constant. Yet, quantitative reconstructions of the past variability in climate requires a more detailed understanding of our proxies; the limitations and effects that may or may not distort our potential archives (Waelbroeck et al., 2005). Not only is there a need for a more detailed understanding 
of the biology of planktonic foraminifera, but also a greater understanding of how the signals from the upper ocean are preserved within their tests. Thus, the application of single specimen analysis to climatic archives with advances in utilising low quantities of carbonate in mass spectrometry allow us a first step for removing the effect of time-averaged signals within conventional isotope analysis. Our method offers the potential to unravel population dynamics and depth migration of planktonic foraminifera as well as bioturbation effects from climate archives in relation to ocean properties and circulation. Future work following our approach may prove to be extremely useful to better understand and model sea surface temperature extremes and seasonal behavior of climate change.

\section{Supplementary material related to this article is available online at: http://www.clim-past.net/7/1337/2011/ cp-7-1337-2011-supplement.pdf.}

Acknowledgements. We thank Victoria Peck for critical comments which helped improving the manuscript. We are grateful to two anonymous reviewers and to the editor, Thorsten Kiefer, who thoroughly evaluated the manuscript twice and improved it a lot by their comments, criticisms and suggestions. F. P. acknowledges sponsoring from N.W.O. EuroMARC program - RETRO, grant number 855.01.121. This is a contribution to the "European Project on Ocean Acidification" (EPOCA)(FP7/211384).

We dedicate this paper to our esteemed colleague Orson van der Plassche, who passed away much too early.

\section{Edited by: T. Kiefer}

\section{References}

Alley, R. B., Mayewski, P. A., Sowers, T., Stuiver, M., Taylor, K. C., and Clark, P. U.: Holocene climatic instability: a prominent, widespread event 8200 years ago, Geology, 25, 483-486, 1997.

Altabet, M. A., Higginson, M. J., and Murray, R. W.: The effect of millennial-scale changes in the Arabian Sea denitrification on atmospheric $\mathrm{CO}_{2}$, Nature, 415, 159-162, 2002.

Anand, P., Elderfield, H., and Conte, M. H.: Calibration of $\mathrm{Mg} / \mathrm{Ca}$ thermometry in planktonic foraminifera from a sediment trap time series, Paleoceanography, 18, 1050, doi:10.1029/2002PA000846, 2003.

Anand, P., Kroon, D., Singh, A. D., and Ganssen, G.: Coupled sea surface temperature-seawater $\delta^{18} \mathrm{O}$ reconstructions in the Arabian Sea at the millennial scale for the last $35 \mathrm{ka}$, Paleoceanography, 23, PA4207, doi:10.1029/2007PA001564, 2008.

Anderson, D. M. and Prell, W. L.: A 300 kyr record of upwelling off Oman during the late Quaternary; evidence of the Asian southwest monsoon, Paleoceanography, 8, 193-208, 1993.

Barker, S., Greaves, M., and Elderfield, H.: A study of cleaning procedures used for foraminiferal $\mathrm{Mg} / \mathrm{Ca}$ paleothermometry, Geochem. Geophy. Geosy., 4, 8407, doi:10.1029/2003GC000559, 2003.
Bé, A. W. H. and Tolderlund, D. S.: Distribution and ecology of living planktonic foraminifera in surface waters of the Atlantic and Indian Oceans, in: Micropaleontology of Oceans, edited by: Funnell, B. M. and Riedel, W. R., Cambridge University Press, London, 105-149, 1971.

Bé, A. W. H., Hemleben, C., Anderson, O.-R., Spindler, M., Hacunda, J., and Tuntivate-Choy, S.: Laboratory and field observations of living planktonic foraminifera, Micropaleontology, 23, 155-179, 1977.

Berger, W. H.: Sedimentation of planktonic foraminifera, Mar. Geol., 11, 325-358, 1971.

Bijma, J., Hemleben, C., and Wellnitz, K.: Lunar-influenced carbonate flux of the planktic foraminifer Globigerinoides sacculifer (Brady) from the central Red Sea, Deep-Sea Res. Pt. I, 41, 511530, 1994.

Clemens, S., Prell, W. L., Murray, D., Shimmield, G. B., and Weedon, G. P.: Forcing mechanisms of the Indian Ocean monsoon, Nature, 353, 720-725, 1991.

Conan, S. M. H. and Brummer, G.-J.: Fluxes of planktic foraminifera in response to monsoonal upwelling on the Somalia Basin margin, Deep-Sea Res. Pt. II, 47, 2207-2227, 2000.

de Villiers, S., Greaves, M., and Elderfield, H.: An intensity ratio calibration method for the accurate determination of $\mathrm{Mg} / \mathrm{Ca}$ and $\mathrm{Sr} / \mathrm{Ca}$ of marine carbonates by ICP-AES, Geochem. Geophy. Geosy., 3, 1001, doi:10.1029/2001GC000169, 2002.

Delaygue, G., Bard, E., Rollion, D., Jouzel, J., Stievenard, M., Duplessy, J.-C., and Ganssen, G.: Oxygen isotope/salinity relationship in the Indian Ocean, J. Geophys. Res., 106, 4565-4574, 2001.

de Moel, H., Ganssen, G. M., Peeters, F. J. C., Jung, S. J. A., Kroon, D., Brummer, G. J. A., and Zeebe, R. E.: Planktic foraminiferal shell thinning in the Arabian Sea due to anthropogenic ocean acidification?, Biogeosciences, 6, 1917-1925, doi:10.5194/bg-61917-2009, 2009.

Elderfield, H. and Ganssen, G.: Past temperature and $\delta^{18} \mathrm{O}$ of surface ocean waters inferred from foraminiferal $\mathrm{Mg} / \mathrm{Ca}$ ratios, $\mathrm{Na}$ ture, 405, 442-444, 2000.

Emiliani, C.: Depth habitats of some species of pelagic foraminifera as indicated by oxygen isotope ratios, Am. J. Sci., 252, 149-158, 1954.

Emiliani, C.: Pleistocene temperatures, J. Geol., 63, 538-579, 1955.

Ganssen, G. M., Brummer, G. J. A., Jung, S. J. A., Kroon, D., and Peeters, F. J. C.: The oxygen isotope composition in planktic foraminifera shells as recorder of maximum seasonal SST variation, Geophys. Res. Abstr., 7, 01775, 2005.

Hemleben, Ch., Spindler, M., and Anderson, O. R.: Modern Planktonic Foraminifera, Springer Verlag, Berlin, 363 pp., 1989.

Hut, G.: Consultants' group meeting on stable isotope reference samples for geochemical and hydrological investigations, Report to the Director General, International Atomic Energy Agency, Vienna, April 1987.

Ivanochko, T. S., Ganeshram, R. S., Brummer, G. J. A., Ganssen, G., Jung, S. J. A., Steven, G., Moreton, S. G., Dick Kroon, D.: Variations in tropical convection as an amplifier of global climate change at the millennial scale, Earth and Planetary Science Letters, 235, 302-314, 2005.

Ivanova, E.: Late Quaternary monsoon history and paleoproductivity of the western Arabian Sea, Phd Thesis, Free University, Amsterdam, 172 pp., 2000. 
Jung, S. J. A. and Kroon D., Quantifying rates of change in ocean conditions with implications for timing of sea level change, Global Planet. Change, 79, 204-213, 2011.

Jung, S. J. A., Ivanova, E., Reichart, G. J., Davies, G. R., Ganssen, G., Kroon, D., and van Hinte, J. E.: Centennial-millenial-scale monsoon variations off Somalia over the last $35 \mathrm{ka}$, in: The tectonic and climatic evolution of the Arabian Sea region, edited by: Clift, P., Kroon, D., Gaedicke, C., and Craig, J., The Geological Society London, London, 341-352, 2002.

Jung, S. J. A., Davies, G. R., Ganssen, G. M., and Kroon, D.: Synchronous Holocene sea surface temperature and rainfall variations in the Asian monsoon system, Quaternary Sci. Rev., 23, 2207-2218, 2004.

Jung, S. J. A., Kroon, D., Ganssen, G., Peeters, F., and Ganeshram, R.: Enhanced Arabian Sea intermediate water flow during glacial North Atlantic cold phases, Earth and Planetary Science Letters, 280, 220-228, 2009.

Killingley, J. S., Johnson, R. F., and Berger, W. H.: Oxygen and carbon isotopes of individual shells of planktonic foraminifera from Ontong-Java Plateau, Equatorial Pacific, Palaeogeogr. Palaeocl., 33, 193-204, 1981.

Kim, S.-T. and O'Neil, J. R.: Equilibrium and nonequilibrium oxygen isotope effects in synthetic carbonates, Geochim. Cosmochim. Acta, 61, 3461-3475, 1997.

Kobashi, T., Severinghaus, J., Brook, E. J., Barnola, J. M., and Grachev, A.: Precise timing and characterization of abrupt climate change 8,200 years ago from air trapped in polar ice, Quaternary Sci. Rev., 26, 1212-1222, 2007.

Koutavas, A., deMenocal, P. B., Olive Col, G. C., and LynchStieglitz, J.: Mid-Holocene El Nino-Southern Oscillation (ENSO) attenuation revealed by individual foraminifera in eastern tropical Pacific sediments, Geology, 34, 993-996, doi:10.1130/G22810A.1, 2006.

Kroon, D. and Ganssen, G.: Northern Indian Ocean upwelling cells and the stable isotope composition of living planktonic foraminifers, Deep-Sea Res., 36, 1219-1236, 1989.

Lea, D. W., Mashiotta, T. A., and Spero, H. J.: Controls on magnesium and strontium uptake in planktonic foraminifera determined by live culturing, Geochim. Cosmochim. Acta, 63, 2369-2379, doi:10.1016/S0016-7037(99)00197-0, 1999.

Leduc, G., Vidal, L., Cartapanis, O., and Bard, E.: Modes of eastern equatorial Pacific thermocline variability: Implications for ENSO dynamics over the last glacial period, Paleoceanography, 24, PA3202, doi:10.1029/2008PA001701, 2009.

Lewis, S. C., LeGrande, A. N., Kelley, M., and Schmidt, G. A.: Water vapour source impacts on oxygen isotope variability in tropical precipitation during Heinrich events, Clim. Past, 6, 325-343, doi:10.5194/cp-6-325-2010, 2010.

Loncaric, N., Brummer, G.-J. A., and Kroon, D.: Lunar cycles and seasonal variations in deposition fluxes of planktic foraminiferal shell carbonate to the deep South Atlantic, Deep-Sea Res. Pt. I, 52, 1175-1186, 2005.

Nürnberg, D., Bijma, J., and Hemleben, C.: Assessing the reliability of magnesium in foraminiferal calcite as a proxy for water mass temperatures, Geochim. Cosmochim. Acta, 60, 803-814, doi:10.1016/0016-7037(95)00446-7, 1996.

Oba, T.: Paleoceanographic information obtained by the isotopic measurement of individual foraminiferal specimens, Proceedings First Internationla Conference Asian Marine Geology, Shanghai
(1988), China Ocean Press, Beijing, 169-180, 1990.

Oba, T.: Oxygen and carbon isotopic composition of of planktonic foraminifera tests collected with sediment traps from the Japan Trench, La mer - Societe franco-japonaise d'oceanographie, 29, 190-192, 1991.

Peeters, F. J. C. and Brummer, G.-J. A.: The seasonal distribution of living planktic foraminfera in the NW Arabian Sea, in: The tectonic and climatic evolution of the Arabian Sea region, Vol. 195, edited by: Clift, P., Kroon, D., Gaedicke, C., and Craig, J., The Geological Society London, 463-497, 2002.

Peeters, F. J. C., Brummer, G.-J. A., and Ganssen, G. M.: The effect of upwelling on the distribution and stable isotope composition of Globigerina bulloides and Globigerinoides ruber (planktic foraminifera) in modern surface waters of the NW Arabian Sea, Global Planet. Change, 34, 269-291, 2002.

Prahl, F. G. and Wakeham, S. G.: Calibration of unsaturation patterns in long-chain ketone compositions for paleotemperature assessment, Nature, 330, 367-369, doi:10.1038/330367a0, 1987.

Saher, M., Jung, S. J. A., Elderfield, H., Greaves, M., and Kroon, D.: Western Arabian Sea SSTs during the last deglaciation, Paleocanography, 22, PA2208, doi:10.1029/2006PA001292, 2007.

Schouten, S., Hopmans, E. C., and Sinninghe Damste, J. S.: Distributional variations in marine crenarchaeotal membrane lipids: A new organic proxy for reconstructing ancient sea water temperatures?, Earth Planet. Sc. Lett., 204, 265-274, doi:10.1016/S0012-821X(02)00979-2, 2002.

Schulz, H., von Rad, U., and Erlenkeuser, H.: Correlation between Arabian Sea and Greenland climate oscillation of the past 110,000 years, Nature, 393, 54-57, 1998.

Shakun, J. D., Burns, S. J., Fleitmann, D., Kramers, J., Matter, A., and Al-Subary, A.: A high-resolution, absolute-dated deglacial speleothem record of Indian Ocean climate from Socotra Island, Yemen, Earth Planet. Sc. Lett., 259, 442-456, doi:10.1016/j.eps1.2007.05.004, 2007.

Singh, A. D., Jung, S. J. A., Darling, K., Ganeshram, R., Ivanochko, T.S., and Kroon, D.: Productivity collapses in the Arabian Sea during glacial cold phases, Paleocanography, 26, PA3210, doi:10.1029/2009PA001923, 2011.

Spero, H. J. and Williams, D. F... Evidence for low salinity surface waters in the Gulf of Mexico over the last 16,000 years, Paleoceanography, 5, 963-975, 1990.

Stott, L. D. and Tang, C. M.: Reassessment of Tropical sea surface $\delta^{18}$ O paleotemperatures, Paleoceanography, 11, 37-56, 1996.

Stuiver, M., Reimer, P. J., Braziunas, T. F.: High-precision radiocarbon age calibration for terrestrial and marine samples, Radiocarbon, 40, 1127-1151, 1998.

Swallow, J. C. and Bruce, J. G.: Current measurements off the Somali coast during the southwest monsoon of 1964, Deep-Sea Res., 13, 861-888, 1966.

Tang, C. M. and Stott, L. D.: Seasonal salinity changes during Mediterranean sapropel deposition 9,000 years B.P.: Evidence from isotopic analyses of individual planktonic foraminifera, $\mathrm{Pa}-$ leoceanography, 8, 473-494, 1993.

Waelbroeck, C., Mulitza, S., Spero, H. J., Dokken, T., Kiefer, T., and Cortijo, E.: A global compilation of late Holocene planktonic $\delta^{18} \mathrm{O}$ : relationship between surface water and $\delta^{18} \mathrm{O}$, Quaternary Sci. Rev., 24, 853-868, 2005. 
Wang, P., Clemens, S., Beaufort, L., Braconnot, P., Ganssen, G., Jian, Z., Kershaw, P., and Sarnthein, M.: Evolution and variability of the Asian monsoon system : State of the art and outstanding issues, Quaternary Sci. Rev., 24, 595-629, 2005.

Wiersma, A. P. and Renssen, H.: Model-data comparison for the 8.2 ka BP event: confirmation of a forcing mechanism by catastrophic drainage of Laurentide Lakes, Quaternary Sci. Rev., 25, 63-88, doi:10.1016/j.quascirev.2005.07.009, 2006.
Wit, J. C., Reichart, G.-J., Jung, S. J. A., and Kroon, D.: Approaches to unravel seasonality in sea surface temperatures using paired single-specimen foraminiferal $\delta^{18} \mathrm{O}$ and $\mathrm{Mg} / \mathrm{Ca}$ analyses, Paleoceanography, 25, PA4220, doi:10.1029/2009PA001857, 2010. 